\title{
The private label realities and the marketing strategy adopted by the organized retail chains in the state of Kerala.
}

\author{
Prasanth $\mathrm{MK}^{1}$, Dr.J.Balan ${ }^{2}$ \\ ${ }^{I}$ (Assistant Professor, Institute of management and Technology Punnapra, Alappuzha, Kerala, India and a PhD \\ scholar at Madurai Kamaraj University, Madurai) \\ ${ }^{2}$ (Associate Professor and Principal in Charge, Madurai Kamaraj University College, Madurai)
}

\begin{abstract}
The private label, the master piece of modern trade outlets is fast changing the future of retail industry in India. The private label plays an important role in the over role profitability of a store. The private labels were considered to be inferior to national brands at the initial stages. At present that notion that has been changed to a certain extent and the private brands are considered to be par with national brands in terms of quality and price. The private labels have well established in developed and emerging economies. The private labels are popular in personal care, home care, processed food, groceries and consumer durables. The present research carried out at the selected retail chains in Kerala such as More, Spencer and Reliance Fresh finds that, the marketing strategy can change the over role scenario of private label.
\end{abstract}

Keywords- Marketing strategy, MTOs, national brands, private label, Retail.

\section{Introduction}

The retail sector in India is the biggest employer after agriculture. It contributes 10 to $11 \%$ of the GDP and $8 \%$ of employment. The total retail outlet in India is estimated to be 12 million. The sector amounts to $\$ 180$ billion market and is six times bigger than that of Thailand and four to five times bigger than that of South Korea and Taiwan. The fifty of the Fortune 500 and 25 of the Asian top 200 companies are retailers. While an estimated 85 percent of retail outlets continue to operate in these traditional formats, the last few years has seen a rise in modern retail formats such as hypermarkets, department stores, multi storied malls, and specialty stores particularly in urban and semi-urban areas. The unorganized retail sector is expected to grow at approximately 10 per cent per annum with sales rising from US\$ 309 billion in 2006-07 to US\$ 496 billion. The organized retail, which constituted a low four per cent of total retail in 2006-07, is estimated to grow at 45-50.In nut shell the unorganized and organized retail are bound not only to co-exist but also accomplish fast and sustained growth in the coming years. This is clearly not a case of a zero sum game as both organized and unorganized retail will see a gigantic scaling up of their activities. The developed economies, the organized retail is in the range of 75-80 per cent whereas in developing economies, the unorganized sector dominates retail business. In order to capitalize and increase category profitability most of the organized chains have introduced store brands. In India also leading players such as More, Reliance Fresh, Nilagiris and Spencer have private brands.

\section{Private Label}

According to Batlas, (1997) store brands or private label brands are brands owned, controlled, and sold exclusively by a retailer.

\section{International private label}

The international private labels can be recognized as being of better quality than local private labels.Batra, (2000) international private labels have an inherent cosmopolitan image, they will be deemed more inspirational, desirable and appealing with higher prestige than local private labels. The international private labels can be counted better leading brands than local private labels. The international labels would like to promote their cosmopolitan image so as to generate greater receptivity to their products which are of foreign origin. It is reasonable to state that consuming international private label products can be associated with more sophisticated personalities than local private label products. That is, the brand personality of international private labels will be perceived superior to local private labels. Blois, (2000), and Hsieh, (2004), the international private labels firms normally spend much on advertising and promotional campaigns across international frontiers and consequently are more available and recognized in multiple countries.Yeoh,(2004)under such a circumstance, international firms are likely to be perceived better introducing reliable products. 


\section{Growth of Private Label in India}

The materialization of organized retailing in India has made private labels a reality. Though, initial growth of private label brands in India has been limited to certain categories like grocery and apparel, it is slowly expanding into other categories as well. One of the expectations of KPMG was that the private label would be holding $25 \%$ market share at the end of 2010 , but it has not come as a reality. Some of the latest marketing research report states that, the share of private label has not crossed $10 \%$ in the organized retail chains in Kerala.

\section{Literature Review}

Preeta H. Vyas, (2007) examines the various sales promotion strategies used as a part of the marketing strategy such as in house and mass media promotions, joint sales promotions etc. The sales promotions are to generate, more store traffic, move excess inventory, and enhance store image and create a price image. The promotions may encourage non buyers to walk in to the store and loyalty programmes may egg on buying more, more often or upgrading to better quality. The exciting promotions also have affinity to generate positive word of mouth and help consumer feel a smart shopper. So not only utilitarian benefits like, saving of money, time or quality up gradation but hedonic benefits like feeling confident, feeling of excitement and entertainment etc. The head retail operations need to understand impact of various types of promotions on consumer behaviour and objectives attained. Gopal Das, (2011) when making sales promotion strategy, the managers consider various parameters so as to make sales promotion an effective one. The demographic parameters have no impact on sales promotion. There are various reasons for the purchase of a product. The consumers purchase somewhat more than the regular purchase when promotions are made. The store location, loyalty does not play a major role in purchase decision making when promotional offer is concerned. So the promotions may have an influence on the consumer behaviour in spite of location dis-advantages. At the same time the future sales promotion cannot make customers wait for it. There are various effects of sales promotion and repeat visit to the store is one among them. The sales promotion strategy can be made by introducing various promotional schemes. When ranking various promotional schemes direct price discount is ranked as number one, buy one get one free as second and buy one get another product free. On the media habits in-store publicity plays a vital role in providing information to the customers followed by television and news paper.Serkan Kilic and M Hakan Altmtas,(2006) made an attempt made to estimate the objective of developing private label from retailer's perspective. The private label are generally developed by retailers for increasing the market share, positioning, developing relationships, cost leadership, increasing profit margins, and competitiveness. Enrique Manzur, Sergio Olavarrieta, Pedro Hidalgo, Pablo Farías and Rodrigo Uribe, (2011) find that the producer's of national brands should spotlight their strategies on obtaining consumer loyalty since loyal consumers showed a weaker attitude toward store brands over and above toward promotions of other national brands, which lower the risk of competition from whichever strategy. The strong outcome of buyers attitude toward store brands and national brand promotions we can see that consumers with a higher smart shopper self-perception tend to like national brand promotions more than store brands. In the eyes of Rajesh Rajaguru and Margaret JekanyikaMatanda, (2011) finds that functional attributes and perceived shopping value influences consumer satisfaction and loyalty. The Retailers need to invest resources to modify the supermarket appeal to offer hedonic and utilitarian value to customer. The fast changeover in retailing format and shoppers orientation towards supermarket suggests the retailers need to focus on functional attributes. The traditional markets require rapid changes in their retailing strategy for survival and to compete with supermarkets. While international players are planning a foray into India's retail sector in single brand and multi brand, the Indian retailing sector should pay substantial attention to functional attributes, consumer motives and shopping value. The consumers' expectations on product quality, assortment and service quality positively influences the perceived shopping value at supermarket background and negatively influences at traditional retail format context in terms of product quality and service quality. Angel F Villarejo-Ramos, (2005). The more the resources the organization devoted to enhance a particular brand, the higher perceived quality the brand was seen to have. The spending on advertising affected the perceived quality, because it increased the associated value of the brand, which helped in the purchase decision. The higher the spending on advertising for the brand, the better the quality of the product as perceived by the consumer, the higher the level of brand awareness and the more relations correlated to the product, forming its brand image. The group of associations linked to the brand increased the favourable attitude towards the product as its recognition and the level of awareness increased. The brand awareness and name recognition enhance consumers' attitudes towards brand and improve its image. Oriah Akir and Md Nor Othman,(2010), indicate that the that consumer behavioural theories may be applicable globally but consumers" tastes, preferences and purchase decisions could be regionally or locally oriented and further influenced by their cultural background and norms. whether the products that the consumers purchase are low involvement products or high involvement products, prior concerns of the businesses and managers or marketers are: consumers involvement in the purchase process, the importance that they place on 
certain product attributes and how significantly others influence their decision making process prior to the purchase, after the purchase is completed and the post-purchase behaviour. Hence, this research is beneficial to managers and marketers to streamline their marketing plans and strategies, in order to capture the mind and heart of the consumers at large. As such, it is imperative for marketers and managers to understand consumer behaviour beyond the marketing stimuli but at the same time should also consider the consumers ${ }^{\text {ee }}$ cultural diversity, customs and norms. Venkatesh Shankar and Ruth N. Bolton,(2004) state that the retailers anticipate their rivals to propose storable merchandise at reliable prices with a serious amount of promotions and foresee that vital products at any retailer are expected to be priced consistently, discounted heavily, and orchestrated with frequent use of displays and feature advertisements. The retailers present high levels of promotions for brands with high preference or brand equity, consistent with the notion of using strong brands as a traffic builder for the store. Serdar Sayman, Stephen J. Hoch, Jagmohan S, and Raju, (2002) views that retailers are interested in category profits rather than the profit from any specific brand. The retailer's positioning decision as choosing the degree of competition between the store brand and each of the national brands in the product category. When assuming a category with two national brands, the store brand should be positioned closer to the leading national brand. The consumers can readily detect retailers' efforts to use the extrinsic cues to position against the leading; this knowledge does not necessarily translate into consumer perceptions that the store brand offers comparable intrinsic quality. The retailer prefers to have a store brand that competes heavily with the national brands. There is a tendency for the store brands to imitate the category leader. It is being seen over a period of time that the store brands perform well in categories with high concentration. William $\mathbf{P}$ Putsis.D Jr and Ravi Dhar, (2001) try to find out the basic factors that drive category expenditure focusing on the impact of promotion. The promotion can increase the category expenditure. The supply side consistent with the individual category and market factors helps to enhances the ability of firms to raise price appear to increase the over role category revenue. The brand managers should determine the appropriate response to competitors marketing activities taking into effect the category size as well as the market share. There is a general perception that retailers are more concerned with volume and profit but the manufactures are concerned with market share. According to M.P Martinez Ruiz, A Molla Descals, M.A Gomez Borja and J.L Rojo-Alvarez,(2006)the short-term price discounts presented in the high-priced brands of the category create sales increase. In case of low-priced brands, price discounts offered do not appear to heighten sales. The price deals used as incentives to increase sales are more effective in the high-priced brands of the category, being the less profitable deals those offered in the low priced brands. The existence of asymmetric cross price effects and neighbourhood cross-price effects. The high-priced high-quality brands have a stronger impact on sales of low-priced low quality brands than the reverse, and that cross-price effects are stronger on the sales of brands with similar prices. The promotional days have a significant and differential impact over the sales boost. For all the brands, the weekend in promotional periods have a positive and differential impact over sales.

\section{Primary Objective}

To find out the marketing strategies adopted by the organized retail chains to market private labels.

\section{Secondary Objective}

- To provide an overview of the private label share and growth rate.

- To anlyse the role of designation in formulating the marketing strategy.

- To analyse the relationship between experience and marketing strategy.

\section{Scope and Significance of the study}

The study covers the daily stores of major retail chain such as Spencer, Reliance Fresh and More in Kerala. The Private label in two categories such as Grocery and FMCG comes under the purview of the study. At present, India is reeling under the blow of retail revolution which is changing the landscape of this country. More and more employment opportunities and infrastructure is shaping up in the retail sector. The study is significant as limited studies were only carried out in the state of Kerala with respect to marketing strategies adopted by the organized players with respect to private label.

\section{Research Methodology}

Based on the pilot study, the sample size of the research was framed at 255 from experts. The expert group consist of store managers, store supervisor and sales force in the floor. The primary data was collected at modern retail outlet by way of schedule and observation. One structured schedule was used for the purpose. The schedule and the questionnaire are used to describe the form on which the questions are printed. A schedule is one which is handled by the interviewer. It is different from a questionnaire in such a way that questionnaire is one which is expected to be filled in by the informant. The reason for using schedule in the present research is that, it can provide more accuracy and convenient to the respondents. Based on the predefined quotas, the 
research endeavoured to obtain a sample which was somewhat representative of experts in the state of Kerala. Apart from the primary data, secondary data were also taken for the study.

\section{Data analysis Procedure}

On conclusion of the survey the 255 expert schedules were fully analysed. A preliminary check was done in the field to identify and remedy any inconsistencies, omissions or obvious mistakes with the schedule completion. Another check was made to alleviate less glaring errors. The data from the schedule was then captured, cleaned, coded and analysed with SPSS.Finally, the data was tested for normality and this was confined to be in order. It was found that in the SPSS, there was less than 0.5 per cent missing value which was replaced with mean values and subsequent to that analysis was conducted. The data was analyzed using statistical package for social science (SPSS V 12.0).Descriptive statistics such as mean and standard deviation were generated to provide an overview of the data. ANOVA for significant difference between designations, and experience with respect marketing strategy.

\section{Result and Discussion}

Table 01: Growth in Retail Outlets in India (Millions).

\begin{tabular}{|l|l|l|l|}
\hline Year & Urban & Rural & Total \\
\hline 1978 & 0.58 & 1.76 & 2.35 \\
\hline 1984 & 0.75 & 2.02 & 2.77 \\
\hline 1990 & 0.94 & 2.42 & 3.36 \\
\hline 1996 & 1.80 & 3.33 & 5.13 \\
\hline
\end{tabular}

(Source www.indiainfoline.com)

The above table shows that, the growth rate of retail outlets in India is almost three fold in urban area, while rural area, it is twofold, when we are comparing 1978 with 1996. But the growth rate is steady over a period of time. More over rural areas having more number of outlets compared with urban area.

Table 02:Top Ten Private Label Markets around the world.

top Ten Private Label Markets Based on Share point Gain

\begin{tabular}{||l|l|l|r|r|r||}
\hline & \multicolumn{1}{|c|}{ CounTRY } & \multicolumn{1}{|c|}{ REGION } & $\begin{array}{c}\text { PL } \\
\text { GROWTH } \\
\text { RATE }\end{array}$ & $\begin{array}{c}\text { MANU } \\
\text { GROWTH } \\
\text { RATE }\end{array}$ & $\begin{array}{c}\text { PL SHARE } \\
\text { POINT } \\
\text { GAIN }\end{array}$ \\
\hline 1 & Spain & Europe & $16 \%$ & $6 \%$ & 1.8 \\
\hline 2 & Slovakia & Emerging Markets & $14 \%$ & $-6 \%$ & 1.6 \\
\hline 3 & Netherlands & Europe & $8 \%$ & $-2 \%$ & 1.6 \\
\hline 4 & Finland & Europe & $16 \%$ & $-3 \%$ & 1.5 \\
\hline 5 & Sweden & Europe & $10 \%$ & $-2 \%$ & 1.4 \\
\hline 6 & France & Europe & $3 \%$ & $-2 \%$ & 1.0 \\
\hline 7 & Germany & Europe & $3 \%$ & $-2 \%$ & 1.0 \\
\hline 8 & Croatia & Emerging Markets & $77 \%$ & $0 \%$ & 0.8 \\
\hline 9 & Hungary & Emerging Markets & $15 \%$ & $5 \%$ & 0.8 \\
\hline 10 & Norway & Europe & $14 \%$ & $1 \%$ & 0.8 \\
\hline
\end{tabular}

(Source: Executive News Report from ACNIELSEN Global Services, September 2005)

From the above table, it is clear that the Croatia having the highest growth rate of PL in Europe and other countries such as Spain, Finland, Hungary, Slovakia and Norway are behind it.

Table 03: The private label share and growth rate by product area.

Private Label Shares and GROWTH RATES by PRODUCt AREA

(BAsed on Value Sales)

\begin{tabular}{|c|c|c|c|c|c|c|c|}
\hline & Product AREa, & PL SHARE & $\begin{array}{c}\text { PL } \\
\text { GROWTH } \\
\end{array}$ & & PRODUCt AREA & PL SHARE & $\begin{array}{c}\text { PL } \\
\text { GROWTH } \\
\end{array}$ \\
\hline 1 & Refrigerated Food & $32 \%$ & $9 \%$ & 8 & Non-Alcoholic Beverages & $12 \%$ & $3 \%$ \\
\hline 2 & Paper, Plastic \& Wraps (PPW) & $31 \%$ & $2 \%$ & 9 & Home Care & $10 \%$ & $2 \%$ \\
\hline 3 & Frozen Food & $25 \%$ & $3 \%$ & 10 & Snacks \& Confectionery & $9 \%$ & $8 \%$ \\
\hline 4 & Pet Food & $21 \%$ & $11 \%$ & 11 & Alcoholic Beverages & $6 \%$ & $3 \%$ \\
\hline 5 & Shelf-Stable Food & $19 \%$ & $5 \%$ & 12 & Personal Care & $5 \%$ & $3 \%$ \\
\hline 6 & Diapers \& Feminine Hygiene & $14 \%$ & $-1 \%$ & 13 & Cosmetics & $2 \%$ & $23 \%$ \\
\hline 7 & Health Care & $14 \%$ & $3 \%$ & 14 & Baby Food & $2 \%$ & $13 \%$ \\
\hline
\end{tabular}


(Source: Executive News Report from ACNIELSEN Global Services, September 2005)

From the above table, on private label share and growth rate in product area, it is clear that the refrigerated food having the highest PL share followed by PPW, Frozen Food and Pet Food. When we are anlysing the growth rate of PL, cosmetics having the highest growth rate followed by baby food, and pet food

Table 04: The share and growth rate of private label by region based on value sales.

\section{SHARE AND GROWTH RATES OF PRIVATE LABEL BY REGION} (BASED ON VALUE SALES)
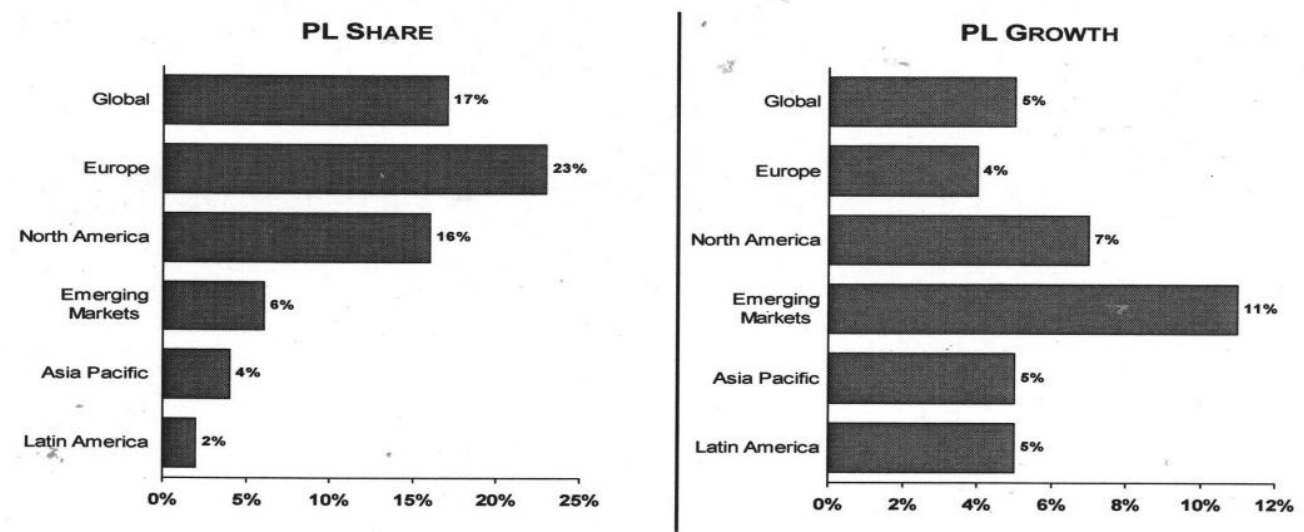

(Source: Executive News Report from ACNIELSEN Global Services, September 2005)

From the chart, on region wise, the Europe having the highest PL share followed by North America and Emerging Markets. The Asia Pacific is behind Europe, North America and emerging markets. In case of PL growth, emerging market is ahead of others. Furthermore Europe is recording low growth rate.

HYPOTHESIS 01

Null Hypothesis: There is no significant difference between designation with respect to marketing strategy.

Table 01ANOVA for significant difference between designations with respect marketing strategy.

\begin{tabular}{|c|c|c|c|c|c|}
\hline \multirow[b]{2}{*}{ Marketing strategy } & \multicolumn{3}{|c|}{ Designation } & \multirow[t]{2}{*}{ F value } & \multirow[t]{2}{*}{ P value } \\
\hline & $\begin{array}{c}\text { Junior } \\
\text { level }\end{array}$ & $\begin{array}{c}\text { Middle } \\
\text { level }\end{array}$ & Senior level & & \\
\hline Product & $\begin{array}{l}10.95_{c} \\
(1.02)\end{array}$ & $\begin{array}{r}7.40_{\mathrm{a}} \\
(3.47)\end{array}$ & $\begin{array}{l}8.69_{\mathrm{b}} \\
(1.23)\end{array}$ & 65.401 & $0.000 * *$ \\
\hline Price & $\begin{array}{l}15.72_{\mathrm{c}} \\
(2.66)\end{array}$ & $\begin{array}{l}11.40_{\mathrm{a}} \\
(2.08)\end{array}$ & $\begin{array}{l}13.25_{\mathrm{b}} \\
(1.99)\end{array}$ & 65.313 & $0.000 * *$ \\
\hline Place & $\begin{array}{r}15.38 b \\
(2.08)\end{array}$ & $\begin{array}{l}14.40_{\mathrm{a}} \\
(2.97)\end{array}$ & $\begin{array}{l}15.43_{\mathrm{b}} \\
(2.50)\end{array}$ & 3.585 & $0.029 *$ \\
\hline Promotion & $\begin{array}{l}30.61_{\mathrm{a}} \\
(3.14)\end{array}$ & $\begin{array}{l}29.80_{\mathrm{a}} \\
(4.66)\end{array}$ & $\begin{array}{l}29.69 \mathrm{a} \\
(2.88)\end{array}$ & 1.953 & 0.144 \\
\hline Overall Marketing Strategy & $\begin{array}{l}72.66_{c} \\
(6.30)\end{array}$ & $\begin{array}{r}63.00_{a} \\
(10.62)\end{array}$ & $\begin{array}{l}67.06_{b} \\
(6.37)\end{array}$ & 29.888 & $0.000 * *$ \\
\hline
\end{tabular}

Note: $1 . * *$ Different alphabet between designation denotes significant at $1 \%$ level using Duncan Multiple Range test.

2. * Different alphabet between designation denotes significant at 5\% level using Duncan Multiple Range test. 
3. The value outside the bracket refers to mean.

4. The value within bracket refers to SD.

Since $\mathrm{P}$ value is less than 0.01 , the null hypothesis is rejected at 1 percent level of significance. Hence concluded that, there is a significant difference between designation with respect to marketing strategy. Based on Duncan Multiple Range test, the marketing strategy adopted for product and price are same with respect to designation. In case of promotion the marketing strategy is same at all levels (junior level, Middle level and senior level).It may be due to the fact that promotion material may be same at all levels.

HYPOTHESIS 02

Null Hypothesis: There is no significant difference between work experience with respect to marketing strategy.

Table 02 ANOVA for significant difference between experience with respect marketing strategy.

\begin{tabular}{|c|c|c|c|c|c|c|c|}
\hline \multirow{2}{*}{\multicolumn{2}{|c|}{ Marketing strategy }} & \multicolumn{4}{|c|}{ No. of years work experience } & \multirow[t]{2}{*}{ F value } & \multirow[t]{2}{*}{ P value } \\
\hline & & \multirow{2}{*}{$\begin{array}{r}\text { Upto } 1 \\
9.14_{\mathrm{b}}\end{array}$} & \multirow{2}{*}{$\frac{1 \text { to } 5}{9.10_{\mathrm{b}}}$} & \multirow{2}{*}{$\begin{array}{r}5 \text { to } 10 \\
10.78_{\mathrm{c}}\end{array}$} & \multirow{2}{*}{$\begin{array}{r}\text { Above } 10 \\
7.00_{\mathrm{a}}\end{array}$} & & \\
\hline Product & Mean & & & & & \multirow{2}{*}{30.883} & \multirow{2}{*}{$0.000 * *$} \\
\hline & SD & (1.61) & (1.23) & $(1.71)$ & (3.58) & & \\
\hline \multirow[t]{2}{*}{ Price } & Mean & $16.17_{\mathrm{b}}$ & $13.24_{\mathrm{a}}$ & $12.65_{\mathrm{a}}$ & $12.75_{\mathrm{a}}$ & \multirow{2}{*}{27.922} & \multirow{2}{*}{$0.000 * *$} \\
\hline & SD & (1.87) & (2.32) & $(0.48)$ & (4.19) & & \\
\hline \multirow[t]{2}{*}{ Place } & Mean & $16.72_{\mathrm{c}}$ & $14.82_{\mathrm{b}}$ & $13.60_{\mathrm{a}}$ & $16.25_{\mathrm{c}}$ & \multirow{2}{*}{24.045} & \multirow{2}{*}{$0.000^{* *}$} \\
\hline & SD & $(2.57)$ & (2.17) & (1.70) & $(2.52)$ & & \\
\hline \multirow[t]{2}{*}{ Promotion } & Mean & $32.97_{\mathrm{d}}$ & $29.52 \mathrm{~b}$ & $27.17_{\mathrm{a}}$ & $31.25_{\mathrm{c}}$ & \multirow{2}{*}{48.748} & \multirow{2}{*}{$0.000 * *$} \\
\hline & SD & (1.93) & (2.02) & (1.69) & $\begin{array}{l}(5.18) \\
\end{array}$ & & \\
\hline \multirow{2}{*}{$\begin{array}{l}\text { Overall } \\
\text { Marketing } \\
\text { Strategy }\end{array}$} & Mean & $75.00_{c}$ & $66.67_{\mathrm{ab}}$ & $64.21_{\mathrm{a}}$ & $67.25_{\mathrm{b}}$ & \multirow[b]{2}{*}{24.581} & \multirow[b]{2}{*}{$0.000 * *$} \\
\hline & SD & (6.27) & (4.95) & (3.55) & (13.88) & & \\
\hline
\end{tabular}

Note: 1. ** Different alphabet between no of years of work experience denotes significant at $1 \%$ level using Duncan Multiple Range test.

Since $\mathrm{P}$ value is less than 0.01 , the null hypothesis is rejected at 1 percent level of significance. Hence concluded that there is a significant difference between experience of staff in organised retail chains with respect to selecting marketing strategy. Based on Duncan Multiple Range test, the marketing strategy adopted for product on staffs having an experience of 1 to 5 years are same. However the marketing strategy for product on staff having 5 to 10 years experience and that of more than 10 years of experience are different. The marketing strategy with regard to pricing for staff above 1 year experience is different than those staff having one year experience. The promotion strategy adopted by marketing professionals of varied experience is different.

\section{Findings}

- In India the rural areas having more number of retail outlets compared with urban area.

- With regard to international situation of PL in various product categories, the refrigerated food having the highest PL share followed by PPW, Frozed Food and Pet Food. On the growth rate of PL, cosmetics having the highest growth rate followed by baby food, and pet food.

- On region wise, the Europe having the highest PL share followed by North America and Emerging Markets.

- The marketing strategy employed in Kerala is different (senior level, middle level and junior level) on the designation wise.

- The experience of staff at the organized retail chains plays a pivotal role in shaping the marketing strategy.

\section{Conclusion and Recommendations}

The success of any MTOs depends up on the marketing strategy formulated and employed at the ground level. At the time of formulating marketing strategies, all the stakeholders in an organized chain such as senior level staff, middle level staff and junior level staff should be consulted and it is proven again and again that, there is no substitute for experience of the staff. It is wise on the part of the modern trade outlets to collect 
feedback from customers before and after the consumption of private labels, as that will provide an extra cushion to the retailers.

\section{References}

[1] G.Baltas, \& P Doyle, An empirical analysis of private brand demand recognising heterogeneous preferences and choice dynamics, The Journal of the Operational Research Society, 49(8), 1998, 790-798.

[2] P. H. Vyas,Sales promotion practices in apparel retail sector and challenges ahead, , Research and Publications, Indian Institute of Management, Ahmadabad, W.P NO-2007-11-02, (2007), 1-13.

[3] G. Das, The effects of retail sales promotion on buying behaviour of customers, Indian Journal of Marketing, Volume: 41(7), 2011,

[4] S.Kilic \& H.Altmtas, Strategic use of private label from retailer's perspective in Turkey, Ankara University, 64(4), 2006, $154-173$.

[5] S.Manzur, E, Olavarrieta,Hidalgo, P,Farías., \& Pand , \&R.Uribe, Store brand and national brand promotion attitudes antecedents, Journal of Business Research, 64, 2011, 286-291.

[6] R.Rajaguru \& M .J Matanda, (Functional Attributes and Shopping Value: Supermarket Vs Local Market, International Journal of Global Business, 4 (2), 2011, 15-27.

[7] A.V Ramos, ,The impact of marketing communication and price promotion on brand equity, Brand Management,12(6), 2005, 431444.

[8] O. Akir \& M.N. Othman, Consumers' Shopping Behaviour Pattern on Selected Consumer Goods: Empirical Evidence on Malaysian Consumers, Journal of Business \& Policy Research, 5(1), 2010, 123 - 157.

[9] 9)V.Shankar \&, R N. Bolton, An empirical analysis of determinants of retailer pricing strategy, Marketing Science,23(1), 2004, 2849.

[10] S. Sayman, S.J Hoch, S. Jagmohan \& Raju,The Positioning of Store Brands, Marketing Science, 21(4), $2002,378-397$.

[11] WP .Putsis \& R.Dhar, An empirical analysis of the determinants of category expenditure, Journal of Business Research, (52), 2001, 277- 291.

[12] M .Ruiz, A.M Descals, M.A.G Borja\& Alvarez, J.L.R., Journal of Retailing, 2006.

[13] Philip Kotler, Marketing Management (New Delhi, Pearson, Eleventh Edition, 2003)

[14] Suja R Nair, Retail Management,(Fourth Edition, Himalaya Publishing House 2009).

[15] Philip Kotler, Kevin Keller, Abraham Koshy \&Mithileshwar Jha, Marketing management, (South Asian Perspective, 13th edition, Dorling KindersleyIndia, Pvt. Ltd, 2009).

[16] V.V Gopal, Retail Management an Introduction (Hyderabad: The ICFAI University Press, India, 2005).

[17] Y.P Sing, Effective Retail Management,(New Delhi: Anmol Publications Pvt.Ltd, 2001).

[18] R, Sudarshan, S. Ravi Prakash.S \& M.S, Sarma, Retail management Principles and Practices (New Delhi: New Century Publications, 2007). 